Научная статья

УДК 316.628

DOI: $10.18101 / 2307-3330-2021-4-4-9$

\title{
ОСОБЕННОСТИ ПРОЯВЛЕНИЯ КОНФОРМИЗМА В МЛАДШЕМ ШКОЛЬНОМ ВОЗРАСТЕ
}

\author{
(C) Абидаева Наталья Сергеевна \\ студентка, \\ Бурятский государственный университет имени Доржи Банзарова \\ Россия, 670000, г. Улан-Удэ, ул. Смолина, 24a \\ aurabidaev@gmail.com

\section{(C) Габеева Лариса Николаевна} \\ кандидат педагогических наук, доцент, \\ Бурятский государственный университет имени Доржи Банзарова \\ Россия, 670000, г. Улан-Удэ, ул. Смолина, 24a \\ gabeevaldar@mail.ru
}

Аннотация. Статья посвящена вопросам проявления конформизма в младшем школьном возрасте. Авторами рассматриваются разные подходы к определению понятия «конформизм», описываются причины его проявления у детей дошкольного и младшего школьного возраста. В статье рассматриваются ситуации, в результате которых младшие школьники становятся более подвержены конформному поведению. Статья содержит описание экспериментального исследования, целью которого является понижение уровня конформности у младших школьников. Приводятся примеры из программы, разработанной и внедренной авторами статьи. В целом отмечается, что при умелом систематическом руководстве педагога у младших школьников будет снижаться уровень конформности и как следствие будет успешнее развиваться их индивидуальность и самооценка.

Ключевые слова: конформизм, конформность, младший школьный возраст, поведение, самооценка.

\section{Для цитирования}

Абидаева Н. С., Габеева Л. Н. Особенности проявления конформизма в младшем школьном возрасте // Вестник Бурятского государственного университета. Образование. Личность. Общество. 2021. № 4. С. 4-9.

\section{Введение}

Младший школьный возраст является важным для целостного развития личности ребенка. Внутренние механизмы психического развития ребенка, особенности влияния социума и вид ведущей деятельности, на наш взгляд, определяют поведение ребенка в обществе.

С психологической точки зрения в младшем школьном возрасте ребенок попадает в совершенно новую для него систему отношений с окружающими его людьми. К нему предъявляются новые, более серьезные требования, возлагается немалая ответственность за свои действия, учебная деятельность требует нормированного отношения и сосредоточения. Безусловно, все эти факторы вызывают у 
ребенка стресс, который отражается на поведении младшего школьника. Он может противиться предъявляемым требованиям со стороны его близких людей или учителя, становясь, тем самым, менее устойчивым к мнению окружающих. Младший школьник может оказаться зависимым от мнения окружающих, желая получить признание своих действий, тем самым ведя к стремлению быть таким, как все. Ребенок находится среди своих сверстников, от которых ему не хочется отставать или быть хуже, чем они, и, следовательно, дети младшего школьного возраста становятся более подверженными конформному поведению. Ввиду своего возраста и небольшого жизненного опыта ребенок еще не осознает, что он индивидуальность и иметь отличия от других - это нормально.

\section{Понятие «конформизм», «конформность»}

Термин «конформизм» впервые нашел свое отражение в социальной психологии и рассматривается как «уступчивость, следование за силой большинства» [5]. Исследуемое понятие произошло от латинского conformis, что переводится «уподобляться», «соответствовать» [3].

С. Аш определял конформизм как «отказ индивида от дорогих и значимых для него взглядов ради того, чтобы оптимизировать процесс адаптации к группе, а отнюдь не любое выравнивание мнений» [1]. В гуманитарных науках дается аналогичное определение. В педагогике Т. Л. Белоусова определяет, конформизм как «тенденцию человека изменять свое поведение под влиянием других людей таким образом, чтобы оно соответствовало мнениям окружающих, стремление приспособить его к их требованиям» [3]. Ученые естественных наук рассматривают конформизм как желание человека адаптироваться к социальным нормам, чтобы максимально имитировать окружающую среду.

Изучая явление конформизма, следует рассматривать понятие «конформность», которое представляет собой склонность к конформизму. Ю. В. Бажданова в своем труде «Исследование особенностей конформного поведения» пишет, что «конформность - склонность к конформизму, к изменению своих взглядов и позиций вслед за теми, которые преобладают в данном обществе, группе или просто значимых окружающих» [2].

Следует отметить, что ряд ученых считают данные понятия синонимичными. По нашему мнению, следует разделять данные понятия с целью конкретизации изучаемых явлений.

Конформизм и конформность связаны с такими процессами, как внушение (усвоение психических состояний и образований - идей, представлений, установок и т. д., одного субъекта другим без должного сознательного контроля, осмысления и рационально-критического отношения к ним), психическое заражение (распространение эмоционального состояния одного субъекта на другого как в связи с передачей значений и смыслов, так и независимо от нее) и подражание (следование какому-либо образцу), которые обеспечивают схожесть или единообразие в поведении людей.

Безусловно, конформное поведение обеспечивает своего рода безопасность для человека и тем более для ребенка, поскольку помогает избегать конфликтных ситуаций, однако, присутствует большая угроза потери своей индивидуальности, затруднения в выражении своего «Я» и в осознании собственных эмоций, желаний 
и формировании полноценного своеобразного и оригинального собственного видения, и ощущения мира.

\section{Проявление конформизма в младшем школьном возрасте}

В дошкольном возрасте в условиях семьи желания ребенка коррелируются родными сознательно или бессознательно с его желаниями возможностями. С поступлением в школу ребенка порой не спрашивают, что он хочет или не хочет, как в дошкольном возрасте. В младшем школьном возрасте жизнь ребенка меняется - нужно ежедневно посещать школу и выполнять требования учебной деятельности. Данные условия становятся для ребенка стрессовыми, и, как следствие, он может воспротивиться общепринятым нормам и правилам поведения. В связи с этим конформное поведение может выступать, как положительный аспект развития личности ребенка. В подобном ключе конформизм становится лишь неким инструментом адаптации и социализации младшего школьника к новым, трудным для него условиям. Ребенок ходит в школу, делает домашние задания, по причине того, что так делают все. Безусловно, в детском саду и в семье ребенка нужно подготовить к новой социальной ситуации развития, объяснять, насколько важна школа, так как некоторые дети бывают не готовы к таким жестким для них условиям.

В сознании младшего школьника школа представляется как строго нормированное время, действия по расписанию, обязательное выполнение домашнего задания, повиновение учителю, дисциплинированность, организованность, ответственность. Кроме того, во многих школах учится по 25 и более детей в классе, изза чего ребенок может страдать от нехватки внимания, к которому он привык дома или в детском саду. Все названные факторы вызывают у ребенка тяжелое психологическое состояние, тревогу, стресс, страх. На подсознательном уровне психика ребенка начинает искать способы выхода из напряженной стрессовой ситуации. Ребенок начинает соотносить свое поведение с поведением сверстников. Ребенок хочет социализироваться, быть с одноклассниками на одном уровне. И он прекрасно осознает, что общие интересы и взгляды на жизнь могут сближать людей. Чаще неосознанно ребенок начинает говорить на языке группы, смотрит те же мультфильмы, играет в те же игры, что и группа. В конечном результате ребенок принимает чужое мнение на себя.

Особенно сильно конформное поведение проявляется в первом классе. Ребенок попадает в новую для него обстановку, чужую и непонятную. Первоклассник очевидно не знает, как себя вести в еще незнакомых для него ситуациях. Понятно, что он начинает повторять за другими, его желание проявляется в том, чтобы подходить под общепринятые требования в классе, которые являются для него нормой и, в некотором смысле, полезной неизбежностью. Ребенку нужно найти общий язык с новой социальной группой. Учитель становится для ребенка фигурой, определяющей его психологическое состояние не только в классе, на уроке и в общении с одноклассниками, но и в семье, так как его влияние простирается и на отношение между близкими и родными людьми.

Проанализировав психолого-педагогическую литературу, мы выяснили, что высококонформные дети имеют заниженную самооценку, «комплекс неполноценности», более зависимы и тревожны, чувствительны к мнениям окружающих. 


\section{Экспериментальное исследование}

В рамках нашей темы нами проведено экспериментальное исследование на базе МОУ Могойтуйской СОШ № 2 им. Шагдарова Республики Бурятия, в котором приняли участие учащиеся третьего класса.

На этапе диагностики мы определили уровень конформности у учащихся. В соответствии с поставленной целью и личностными характеристиками испытуемых, нами были подобраны следующие известные диагностические методики:

- методика «Сладкая соленая каша» (В. С. Мухина);

- методика «Обе белые» (В. С. Мухина);

- методика «Школьная жизнь» (Соломон Аш).

По результатам проведенных методик многие учащиеся поддавались мнению большинства и говорили, что «каша соленая» или «пирамидки белые». Исследование на конформность показало, что большинство $(65 \%)$ детей оказались внушаемы и зависимы от мнения окружающих. Тесты наглядно продемонстрировали, что ребенок может менять свое мнение или намеренно искажать реальную ситуацию под воздействием мнения большинства. У $35 \%$ испытуемых средний (норма) уровень конформности: дети имеют свою точку зрения, менее пассивны в суждениях, более раскрепощены, решения предпочитают принимать самостоятельно.

Данные диагностического исследования показали необходимость проведения работы, направленной на понижение уровня конформности у детей. В связи с этим, нами разработана и реализована программа «Я личность», целью которой является коррекция конформного поведения младших школьников.

Данная программа представляет собой комплекс внеурочных занятий с использованием различных игровых форм и методов работы, так как младшие школьники активнее всего участвуют в процессе проведения различных игр. Безусловно, игра дает положительный результат ввиду того, что наиболее интересна детям, рассчитана на их возраст и дети чувствуют в ней себя непринужденно. Мы предположили, что использование игр является одним из методов снижения уровня конформности у младших школьников.

К примеру, рассмотрим содержание психотехнической игры «Я могу», направленной на раскрепощение конформных детей, путем специальных игровых упражнений, в виде игровых формул. Для нерешительного, скованного ребенка с конформным поведением игровые формулы-внушения могут быть такими: «Я смелый и решительный. Выйду сейчас в центр круга и громко хлопну в ладоши», «Сейчас я никого не боюсь», «Я могу сам...», «Я уже научился...» и т. д.

Одновременно с психотехническими играми конформные дети вовлекаются и в образно-ролевые игры. Например, ребенок может исполнить роль зайчика, но при этом создать различные образы этого зайчика: смелого, слабого, трусливого, непослушного и др.

Важно отметить, что снижение уровня подверженности конформизму происходит также в процессе выполнения творческих заданий, например, рисования, лепки, написания своих рассказов и т.д., Например, на одном из занятий в процессе реализации программы нами было замечено, что при индивидуальной работе с одним из испытуемых (Андрей), мальчик не способен был придумать тему 
для своего рисунка или рассказа самостоятельно. Ребенку постоянно хотелось обратиться за помощью к одноклассникам или к учителю, но в процессе беседы «Я могу», организованной с целью создания благоприятного психологического климата, мальчик почувствовал расслабление и уверенность в своих силах, в результате чего справился с заданием самостоятельно, придумывая оригинальные идеи в своей творческой деятельности. Подобным образом была организована индивидуальная работа с каждым из учащихся.

Фронтальные формы работы с детьми осуществлялись в процессе игр. Например, в психотехнической игре «Докажи» учащимся предлагалось определенное утверждение, например, общепринятое выражение или пословица («век живи - век учись», «мы в ответе за тех, кого приручили» и т. д.). Задачей для детей стояла доказать или опровергнуть выдвинутое положение. Кроме того, был добавлен соревновательный момент, кто больше приведет доказательств, тот выигрывает. В данной игре младшие школьники учатся доказывать личное мнение и отстаивать свою точку зрения.

Интересной формой проведения занятий, на наш взгляд, являются психологические беседы в непринужденной обстановке. С учащимися обсуждают неоднозначные вопросы, которые не имеют точного ответа. К примеру, «нужно ли ставить оценки в школе?». Содержание бесед направлено на то, чтобы младший школьник учился рассматривать заданную проблему под разными «углами» и развивать критическое мышление.

На заключительном этапе эксперимента была повторно проведена диагностика уровня конформности у младших школьников с целью выявления эффективности, разработанной нами программы. Итоги тестов показали, что $24 \%$ учащихся дали ложные ответы на предоставленные вопросы, полагаясь на чужое мнение. Остальные дети оказались на среднем (норма) уровне. Испытуемые начали формировать собственную точку зрения, к мнению других стали относиться более критично, стали независимы в суждениях и чаще принимали самостоятельные решения. Анализ динамики в процессе экспериментального исследования показывает заметное улучшение всех показателей уровня конформности у младших школьников.

Таким образом, использование педагогом начальной школы различных методов, форм и средств обучения позволяет снизить уровень конформности у детей, что позволяет им развивать свою индивидуальность, характер, самостоятельность в суждениях и самооценку.

\section{Лuтература}

1. Аш С. Э. Мнение окружающих и социальное давление. Москва: Флинт, 2014. 74 с. Текст: непосредственный.

2. Бажданова Ю. В. Исследование особенностей конформного поведения // Научное мнение. 2018. № 11. С. 117-124. Текст: непосредственный.

3. Белоусова Т. Л. Духовно-нравственное развитие и воспитание младших школьников: методические рекомендации: в 2 ч. Москва: Просвещение, 2017. Ч. 2. 144 с. Текст: непосредственный.

4. Бордовская Н. В. Психология и педагогика. Санкт-Петербург: Питер, 2018. 320 с. Текст: непосредственный. 
5. Гашкова К. А. Исследование психологии младшего школьника. Екатеринбург: АМБ, 2019. 67 с. Текст: непосредственный.

Статья поступила в редакиию 02.10.2021; одобрена после рецензирования 13.10.2021; принята к публикации 15.12.2021.

\title{
CONFORMISM DEMOSTRATION PECULIARITIES AMONG PRIMARY SCHOOL CHILDREN
}

\author{
Natalya S. Abidaeva \\ Student, \\ Banzarov Buryat State University, \\ 24a Smolina St., Ulan-Ude, 670000, Russia \\ aurabidaev@gmail.com

\section{Larisa N. Gabeeva} \\ Candidate of Pedagogical sciences, Associate Professor, \\ Banzarov Buryat State University, \\ 24a Smolina St., Ulan-Ude, 670000, Russia \\ gabeevaldar@mail.ru
}

The paper is about the issues of conformism demonstration among primary school children. The authors consider various approaches to the definition of "conformism" concept; describe the reasons for its development among preschool and primary school children. The article examines situations when primary school children have conformism proneness. The paper includes a description of an experimental study aimed at lowering the conformity level among primary school children and examples from the program developed and implemented by the authors of the paper. In general, it is noted that under the skillful systematic guidance of a teacher, the conformity level among primary school children will decrease. As a result, their individuality and self-esteem will successfully develop.

Keywords: conformism, conformity, primary school age, behavior, self-esteem.

The article was submitted 02.10.2021; approved after reviewing 13.10.2021; accepted for publication 15.12.2021. 